\title{
Testing the Existence of Government Regulations in the Legal Regulation System in Indonesia
}

\author{
Isnu Harjo Prayitno ${ }^{1}$, Musa Anthony Siregar ${ }^{2}$ \\ \{ isnuhp@gmail.com ${ }^{1}$, m_sireg@yahoo.com² ${ }^{2}$ \} \\ ${ }^{1,2}$ Postgraduate Jayabaya University, Indonesia
}

\begin{abstract}
Existence Rule Government in System Regulations Regulations in Indonesia is considered to be one of the inhibitors in the enforcement of law in Indonesia, due to the implementation of Act became hostage without the issuance of Regulations Government. Evidently there are many laws which can not be implemented immediately into society because of Rule Government which did not immediately issue when have got devolution, so that people are harmed. Regulation of the Government by Decree President also has the role and function almost the same, becomes ambivalence government in issuing the rules are in the system of regulatory legislation. Research is using the approach of juridical normative in the formation of Rule Government who entered into the system formation of regulatory legislation.
\end{abstract}

Keyword: Rule Government, System Regulation Legislation, Certainty Law

\section{Introduction}

The history of law can be said to be experiencing sometimes change and improvement. Starting with the legislation that has been passed down by the colonial Dutch had colonized nation Indonesia is quite a long time until the formation of a hierarchy of legislation are considered to be good and in accordance of the needs in the state administration in Indonesia through Law No. 12 of 2011 concerning Formation of Regulations and Regulations . Although Law No.12 of 2011 finally experienced a change also with the enactment of Law No. 15 Year 2019 to cover the shortage of Act No. 12 Year 2011.

But based on the deepening of the material Law No. 15 Year 2019 even this is considered to be still there are cracks that still be the problem of the level in the field, especially against the existence of regulation has, Rule Government and regulation. But at least that development has led to improvements in the issue regarding the formation of legislation.

Regulation of the government in the theory of the formation of regulatory legislation is classified as a regulation implementing (verordnorm) as a theory that stated by Hans Nawiasky pupil of Hans Kelsen as theory Stufenbau theories, Regulations implementation of this function to 
provide regulation that is more technical than the rules above that legislation (formalgezet). So with the regulations of government, laws could be applied in the technical field.

However, precisely to create its own problems in the field. When the legislation has been enacted and has been valid but the issuance of regulations the government did not immediately do the things it can give rise to uncertainty law. Which in the end is a society that is harmed by not any rules that clearly would pose problems of law new. An example is the Law No.11 Year 2008 on Pornography which is new there are Government Regulation its Year 2011, Law 6 Year 2018 on Quarantine Health recently published Government Regulation in the year 2020 and even then more specifically related to the handling of Covid-19. Including the Act 18 Year 2003 concerning Advocates that without PP until the problem is more complicated because it had a lot of norms new that binds him to the problems organizations advocate the single bar corresponding mandate of the Act becomes increasingly not clear.

\section{Method}

The study is based to some theory of law that is known widely as the theory of the history of law Von Savigny, the theory of certainty, justice and the emergence Gustav Radbrouch and Stufen theory of Hans Kelsen and Hans Nawiasky. Authors see yet any research that depth is specifically related to Rule Government within the system law in Indonesia. The study was conducted based on normative juridical research of primary and secondary materials. It is expected that through the assessment of this can be obtained data is accurate about the issues that will be studied with the rules of the norms of the new.

\section{Results and Discussion}

System Legislation in Indonesia is a continuation of the system of law that has been there since the time of the colonial Dutch. When the Netherlands there is a change in system his state included in the formation of its laws so states colonies are directly or not directly receive the impact. [1] The Netherlands formulate a constitution written in the form of legislation base is done in year 1848 [2]. Then followed the laws related to civil and criminal who started imposed on his country by adopting of a law in France which subsequently also applied in Indonesia that we are familiar with the Criminal Code, Code Civil and to Code of Businesses Law.

In the history of the colonial Dutch never impose some regulatory legislation in Indonesia which time it was named Indies Netherlands among others, namely Wet, Algemene Matregel van Bestuur and Ordinance of the same level the Act. Then there are Regerings Verordening at the level of Government Regulations, Besluit Gouvernoor General at the level of Presidential Decrees, Besluit Departement Shoofde at the level of Ministerial Decrees and Besluit Staatsbedrijf at the level of State Agency Decrees. Not yet added regulations at the level of local as Locale Verordening, Waterschamps Verordening and Verordening Hoof Gewest Bestuur. [3]

Furthermore, when Indonesia liberate ourselves on the date of 17 August 1945, the Dutch did not and immediately recognize the independence of Indonesia. The Netherlands tried to stick his power back in Indonesia once seized by Japan in the year 1942. Some of the regulatory legislation of the Netherlands were changed by the Japanese attempted to in return by the Netherlands. But 
the effort was not easy due to plugging back the power in Indonesia, the Netherlands had to fight in the physical as well as the path of diplomacy to end the Netherlands recognizes the sovereignty of the Republic of Indonesia in the year 1949.

According to Shidarta, Frederich Karl von Savigny (1779-1861), a historical legal theory figure, said that law did not need to be made because law grew with the people. Law is not a product by design. He grew follow a process that runs in the diachronic. Laws in Savigny's eyes do not recognize the word stop (cessation). The process that continues to run, so that the law is a product of culture which historically. Because if this process stops and the law becomes a momentary, then the law has the potential to be uprooted from its historical roots. He became a product of political, product by design should view the positivism law. [4]

While it did nature through Home Visits certainty, justice and benefit of law which was developed by Gustav Radbruch, certainty, fairness and expediency the three objectives of law. According fairness, certainty of law and expediency (Gerechtigkeit, Rechtssicherheit, Zweckmäßigkeit) are three terms that are often sung in halls lecture and chambers of justice, but not necessarily understood nature or agreed upon meaning. Justice and legal certainty, for example. At first glance the two terms were opposite each other, but may be also not so. [5]

The word justice may be terms analogue, so it presented the term justice procedural, justice legalists, justice commutative, justice distributive, justice vindikatif, justice creative, justice substantive, and so on. Justice procedural, as termed by Nonet and Selznick to mention one of the indicators of the type of law autonomously, for example, it turns out after scrutiny leads to the certainty of law for the sake of upholding the rule of law. So, in this context justice and legal certainty do not cross, but rather are side by side. Fairness and certainty are two values Axiological in the law. The discourse of philosophy of law is often questioned the value of this as if both an antinomy, so the philosophy of law is defined as a search on justice or certainty that justice.

Gustav Radbruch saw mean that the certainty of the law does not always have to be given priority fulfillment in every system of law positively, as if the certainty of the law it should be no more first, just then justice and expediency. So he then rectified his own theory if the third goal of law is equal.

In Historically, the first by Gustav Radbruch purpose certainty occupy the rank of the most over at the destination to another. However, after seeing the fact that the theory of the German in the bottom of the power of the Nazi legalize practices that are not humane during the period of War World II by road making laws which legalize practices of the atrocities of war at the time was , Radbruch was finally rectify the theory that at the top with put the goal of justice in the top destinations of law to another.

Gustav Radbruch proposed 4 (four) things fundamentally that is associated with the meaning of the certainty of law, namely :

1. That the law was positive, it means that the law positively it is law.

2. That the law is based on facts , the meaning is based on reality.

3. That fact should be formulated in a way that is clear so as to avoid errors in interpretation, in addition to easily implemented.

4. Positive law can not be easily changed.[6]

The laws and regulations are arranged in stages which consist of legal norms. Norms norms of law that form the pyramid is that then called with the composition of the norm, which is the 
norm of law is written is called the pyramid law or which are substances called hierarchy of legislation .

Before knowing the theory of general of the pyramid legislation, especially formerly known is the theory Stufenbau (Stufenbau des rechts Theorie) were presented by Hans Kelsen. He said as follows: "Every grammar rule of law is an arrangement rather than rules (Stufenbau des rechts Theory) in peak stufenbau there are rules basis of a system of law national who is a rule fundamental. These basic rules are grundnorm or ursprungnorm. Grundnorm are legal principles that are abstract, general and hypothetical, then move to generallenorm (legal rules), which are further posited to become a real norm (concrettenorm)."

Norms norms of law tiered and level in a hierarchy of governance arrangement, and a norm which is lower applicable, sourced, and based on the norms that much higher. It 's caused so not no regulation legislation that mutually contradict one each other, both were opposed in the vertical (regulation legislation that is lower odds with the much higher levels of hierarchy) as well as horizontally (regulation legislation that rank parallel to each other contradict one each other). [7]

Related composition laws and the types of regulatory legislation in Indonesia had been governed by an official by the government that in the letter the President to the Chairman of the DPR-GR No. 2262 / HK / 59 dated 30 August, 1959, while the order sequence regulation legislation is formally set first times in Decision Assembly Consultative People While the Republic of Indonesia Number XX / MPR / 1966 of the Memorandum of DPR-GR about Source Conduct Law of the Republic of Indonesia and the Rules of Order legislation of the Republic of Indonesia. Then change based on MPR Decree Number III / MPR / 2000 concerning Legal Sources and Regulatory Order. Then replaced again by basing on the statute, namely Law No. 10 Year 2004 concerning the Establishment of Rules Regulations and the latter as well as the renewal of Law No. 12 Year 2011 to change some in the Act No. 15 of 2019.

In the arrangement or hierarchy and the type of regulatory legislation based on the Act 12 Year 2011 Article 7 stated :

1. The Constitution of the Republic of Indonesia

2. Decree of the People 's Consultative Assembly

3. Act / Regulations Government Lieu of Law

4. Government Regulations

5. Presidential Regulation

6. Provincial Regional Regulations ; and

7. Regulation of the Regional District / City

What is interesting and the writer is highlighting is the type of regulation in the form of Government Regulation. Because s ince the beginning of the history of the formation of regulatory legislation existence is always there in the system of regulation law in Indonesia. Though its function is almost equal to the Regulation of President which is the hierarchy is below. For example, Law No.12 of 2011 concerning Formation of Regulations and Regulations uses the implementing regulations namely Presidential Regulations rather than Government Regulations as they should.

Government regulations in their journey become very important because of their function as implementing regulations of the laws above. Because its function is, ultimately many laws that are not able to run with effectively without the Rule Government, although the rules cover listed apply from the date the legislation is enacted. 
For example, Law No. 6 year 2018 about Quarantine Healthy has been applicable since enacted in the year 2018 but not immediately published Rule Government. It's become anomali in the world of law, because although it already applies, but is not able to run as it should. Regulation of the Government finally published in the year 2020 due to the pandemic Covid-19. So that the material that there is in it more specific to the Covid-19 instead of the provisions of that expected from the law. [8]

By making Government Regulations as implementing regulations of the Act, its position is very strategic in accompanying the existence of the Act. Although the existence of the Act itself is not all require the issuance of a Regulation of the Government as a regulation implementing, but when it is already contained in the provisions of the lid then become mandatory for issuance of Rule Government.

The problem is when the legislation has been passed and enacted while in publishing Regulation Governments have not known when the time. In this case if there are legal issues and are brought to the direction of litigation then new legal problems will arise. There is a gap uncertainty of the law as yet the rules implementing the set.

In a product legislation that will be enacted not be separated from the problem that power legitimate, power use, power belts and power behavior. Under the terms of the following explanation. First, legitimate power ; i.e. a regulatory law has validity if it is formed by a norm that is higher or institution that is authorized to shape. A Rule Government will be valid if it is formed by the President to carry out the Act and based on Article 5 paragraph (2) of the 1945 Constitution or a Decree of the President which was formed by the President by Article 4 paragraph (1) 1945. This means that if a product regulation legislation established by the institution which is not authority -based attribution and delegation then not valid or not valid .

Second power for that; a regulatory law does not have its usefulness because as the norm that regulates which aims to replace the formula in a regulatory law but not by doing the revocation of the provisions which amended it. An example is the existence of MPR Decree No.III / MPR / 2000 concerning Legal Sources and Order of Laws and Regulations with the enactment of Law No. 10 of 2004 concerning Formation of Regulations and Regulations. By because it formed the Decree of MPR No.I / MPR / 2003 on An overview Against Material and Legal Status Decree of the Assembly, the Decree of MPR RI Year 1960 until the Year 2002, which in Article 4 digits 4 states Stipulation of MPR No.III / MPR / 2000 declared still remain valid until the formation of the Act .

The third is the power tie of a regulation legislation that has been enacted . In principle, a regulation legislation will be binding in general if it had been enacted with evidence got numbering and sheets country. Without the existence of things that are considered still not be enforced .

The fourth is the conduct, namely ; a regulatory legislation may apply when already enacted, as well as power tie. The difference is in terms of the provisions that exist in the matter of laws applicable to public, but sometimes is not binding because it revoked the phrasa particular due to have received a judicial review of the Supreme Constitutional . [9]

In connection establishment Rule Government, The should natural formation Act, it simultaneously can be in the study also Rule Government. It is to prevent or closing the gap to the lack of certainty of law which can be detrimental to the parties or stakeholders. Becauses, effectively, when the discussion of material from regulation legislation has been discussed also in detail and depth -related materials such. All parties related to both of the elements of the 
government, Parliament, public or stakeholder has been presented. So, when Act was already ready for promulgation, in essence already prepared also in the level of implementation. By because it should be done also publication of Regulation Government it coincided with the law. Then no longer be known term legislation applicable since its enactment but contains noncertainty of law.

As we all know $d$ natural process of the formation of regulatory law states the process of making regulation legislation that basically starts from the planning, preparation, formulation, discussion, endorsement or promulgation and dissemination [10]. The time is long enough to discuss a law. All stages of the need of the time were not a little, even sometimes cannot correspond with the time that is specified or postponed.

In since the receipt of the letter tentan submission of the bill from the House of Representatives that is no later than 60 days, the President appointed the Minister who was assigned to represent the President to discuss the bill together with the President [11]. With such a team from the ministry were linked to discuss more about related material from the bill that that could be material to Rule Government later.

In the process establishment of a regulatory law there are many stages so that the possible outcome of the material legislation is very comprehensive in the set. Most do not exist Discussion Level I and Discussion Level II prior to the passing of a bill [12]. Even before the talks Level I and Discussion Level II, most are not already prepared manuscript academic and drafting of Act are ready to be discussed. 


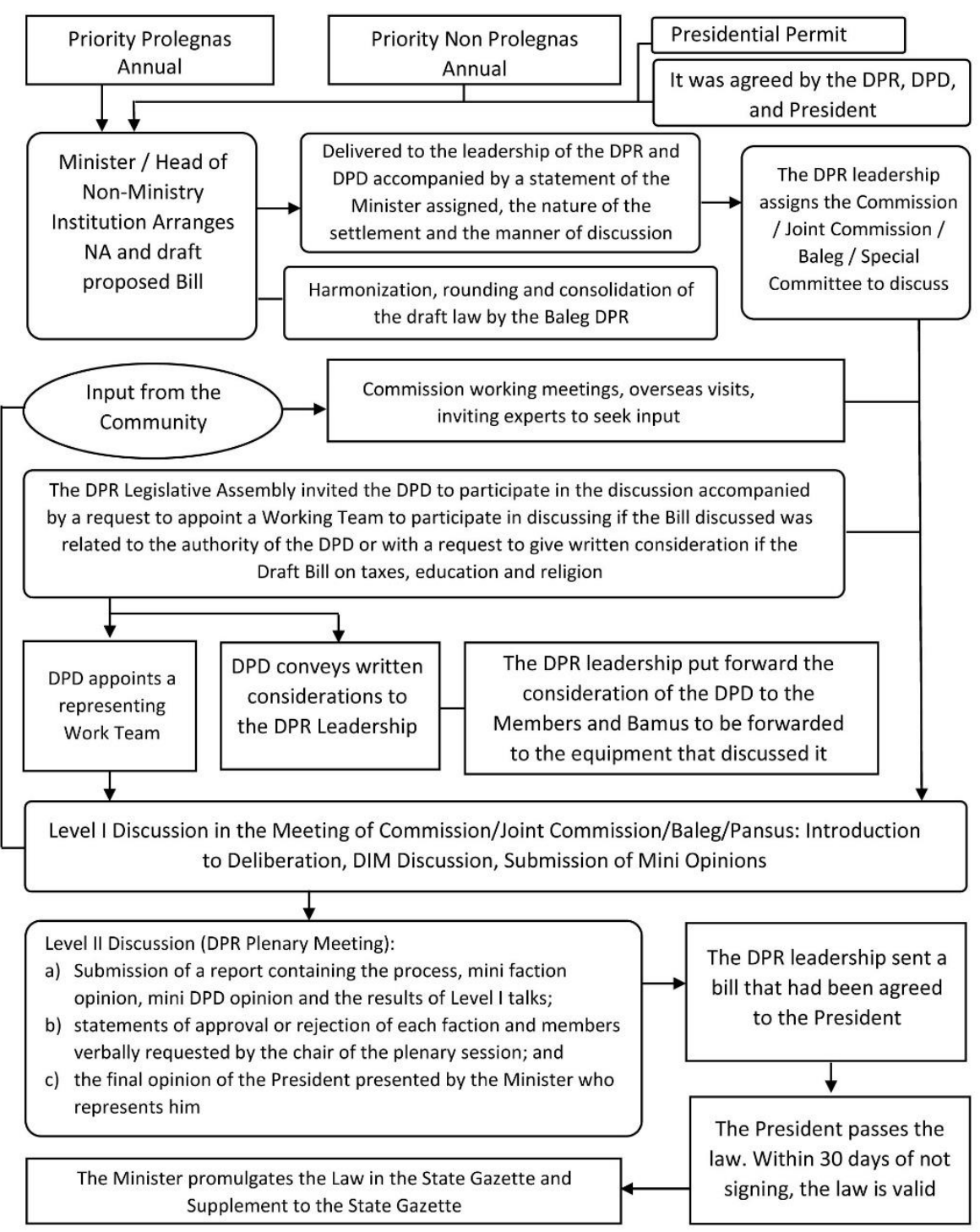

Figure 1. Process Flow Formation of the Law from the Government Proposed Draft Bill

Picture above is one of the examples of the process flow of the formation of an Act through the proposal of the government. The proposal of the House of Representatives and the House in general is almost the same in the process, the only course where the proposal was coming. The process of formation up until the issuance requires time which is quite long so it is expected to get the material from the Act are very mature . 
By thus in principle, when an Act about to be formed should be able to also establish the concept of Rule Government. Because the material that there is in fact already done has been reviewed by all parties both from the elements legislative, elements of executives, stakeholders and the public general. By because it is not no harm if when of Act want passed the Regulation of the Government which has been delegated under the provisions of the lid simultaneously also in the publication. Or if it is not possible to delegate Government Regulations, it is better for the law to be more detailed so there is no need for implementing regulations. Excluded if there are problems specific future days which requires Rule Government.

\section{Conclusion}

System Regulation Legislation in Indonesia in essence a continuation of system Legislation past colonial Dutch. Existence Rule Government the same level with the name Regering Verordening to function as a regulatory executor of the Act which ended in declarated in 1945 in Article 5 paragraph (2). However, with the problems that arise and the results of research based on the study of empirical and normative, the existence of Regulation of the Government should be regulated much better again, especially in the promulgation of the Act which mandates the Regulation of the Government but not immediately accompanied by the issuance of Rule Government. Even though the law has been in force since it was enacted. It is causing inconsistencies law and the uncertainty of the law. Therefore we recommend the publication of Regulation Government who received the delegation on the provisions of the lid then coincided with the promulgation of its laws. Or if it is not possible then just break down the law so that there is no need for implementing regulations in the form of Government Regulations whose scope is the same as the law.

\section{Acknowledgment}

The author would like to thank you for the Rector University Jayabaya and Dean Postgraduate Program Doctoral Studies of Law University of Jayabaya for providing facilities to join the Conference of the International IC ILS 2020 UNNES.

\section{References}

[1] Soetandyo Wignjosoebroto, From colonial law to national law: a study of the sociopolitical dynamics in the development of law for a century and a half in Indonesia, 1840-1990, Cet. 1 (Jakarta: RajaGrafindo Persada, 1994). Thing. 2

[2] Wignjosoebroto. Ibid. Thing. 6

[3] Maria Farida, Legislation, Process and Formation Techniques, 2 ed. (Canisius Publisher, 2007). Thing. 206-207

[4] Shidarta, "The Role of the Intellectual Community of Ala Von Savigny," Rubric Faculty Members (blog), 9 February 2017, business-law.binus.ac.id/2017/09/02/peran-komunitasintelellectual-ala-von -Ssavigny. 
[5] Mario Julyano and Aditya Yuli Setiawan, "Understanding of the Principle of Legal Certainty Through Constructive Reasoning of Legal Positivism," Journal of Crepido 01 (July 2019).

[6] Nur Agus Susanto, "The Axiological Dimension of 'ST,' Case Verdicts" Judicial Journal 7 (March 12, 2014).

[7] A. Rosyid Al Atok, The concept of forming legislation: theory, history, and comparison with several bicameral countries, Revised edition (Malang: Setara Press, 2015). Pg.16

[8] Jimly Asshidiqie delivered in an online lecture via Zoom entitled "Indonesia Emergency Covid19, Development of Emergency HTN in Indonesia ", Thursday 30 April 2020

[9] Farida, Legislation, Process and Formation Techniques . Issue 1. Publisher Kanisius, Jakarta. Pg 39

[10] Republic of Indonesia, Law Number 12 Year 2011, Article 1 Paragraph (1)

[11] Republic of Indonesia, Law Number 17 Year 2014, Article 130 Paragraph (1)

[12] Al Atok, The concept of forming legislation . Ibid. p. 154 